\title{
Debate: Donald Trump and Fascism Studies
}

\author{
Paul Nicholas Jackson \\ University of Northampton Northampton, United Kingdom \\ Paul.Jackson@northampton.ac.uk
}

\begin{abstract}
Since coming to prominence, Donald Trump's politics has regularly been likened to fascism. Many experts within fascism studies have tried to engage with wider media and political debates on the relevance (or otherwise) of such comparisons. In the debate 'Donald Trump and Fascism Studies' we have invited leading academics with connections to the journal and those who are familiar with debates within fascism studies, to offer thoughts on how to consider the complex relationship between fascism, the politics of Donald Trump, and the wider MAGA movement. Contributors to this debat are: Mattias Gardell, Ruth Wodak, Benjamin R. Teitelbaum, David Renton, Nigel Copsey, Raul Cârstocea, Maria Bucur, Brian Hughes, and Roger Griffin.
\end{abstract}

\section{Keywords}

United States - fascism - Donald Trump (1946-)

Since coming to prominence, Donald Trump's politics has regularly been likened to fascism. Many experts within fascism studies have tried to engage with wider media and political debates on the relevance (or otherwise) of such comparisons. Most have urged that contrasts should be drawn between the fascist past and whatever we might want to term the present, though no-one seems to suggest there are no similarities between Trump's politics and fascism (however it may be defined). Moreover, many have suggested that fascist elements operate within at least part of the wider movement - or set of movements - that have developed around Trump's politics.

Following the unprecedented events of 6 January 2021 in America, some voices in this debate also felt that things had changed. Most notably, Robert 
Paxton, who had previously resisted categorising Trump as a fascist, wrote an article for Newsweek explaining: 'Trump's incitement of the invasion of the Capitol on January 6, 2020 removes my objection to the fascist label. His open encouragement of civic violence to overturn an election crosses a red line. The label now seems not just acceptable but necessary.'

At Fascism, we have invited leading academics with connections to the journal and those who are familiar with debates within fascism studies, to offer thoughts on how to consider the complex relationship between fascism, the politics of Donald Trump, and the wider MAGa movement. We asked contributors to limit their comments to a short statement of around five hundred words, and these collectively have been able to capture a range of important observations for future scholarly analysis of these issues. It is hoped these commentaries will help develop this debate in analytically constructive ways, and in particular prove useful for those engaged in researching contemporary forms of fascism, as well as the wider extreme and populist radical right.

\section{Mattias Gardell, Professor at the Centre for Multidisciplinary Studies on Racism, University of Uppsala}

Does Trump and the political force he unleashed signal the return of fascism to mainstream politics? If so, in what respect? Discussing whether Trump himself is a fascist may not be the most fruitful endeavour. Trump may be many things; a narcissist with a grandiose sense of self, a compulsive confabulator, a populist charlatan, but there is not much to indicate that he is politically conscious, or even interested enough to have adopted an ideology of any sort, including fascism. Yet, his MAGA campaign positioned the key fascist vision of national rebirth at the centre of political attention, and we are well advised to remember that also Hitler and Mussolini could be dismissed as egomaniacs, half-insane rascals, big-mouths, and buffoons, by mainstream commentators at the time.

The MAGA vision obviously touches a nerve in popular, predominantly white, American imagination, nurtured by layers of (not always frictionless) banal nationalism, Americanism, nativism, white supremacy, manifest destiny, and racialized discourse and practice. White liberal Americans were chocked when Trump in 2016 gained 63 million votes, Black Americans less so. 'This is the US we know', one of my old African American interlocutors said. If fascism gains a hold in the mainstream, it will grow from within. This informs us that fascism

1 Robert Paxton, 'I've hesitated to Call Donald Trup a Fascist. Until Now,' Newsweek, January 11, 2021, accessed February 21, 2021, https://www.newsweek.com/robert-paxton-trump-fascist-1560652. 
should not be seen as alien to, but part of, the societies in which it competes for hegemony. Of course, no society exists in isolation. The breakthrough of Trump and the MAGA campaign cannot only be explained by domestic factors, but should also be studied in relation to the current surge of radical nationalisms around the world, and the process of globalization they are part and protest of.

A key driver of the MAGA campaign is politicized nostalgia, by which the anxieties of the present are contrasted to the imagined happiness of a lost/ stolen/abandoned, but not undead past. Of course, nostalgia is not exclusive to fascism, but permeates popular culture as evidenced by retro style trends in design, fashion, art, music, and film. This is important as a return of fascist elements to mainstream politics requires their embeddedness in popular desire. Marketing the past may make people miss what they never had, and hence cannot have lost, which may open an avenue for mainstreaming the yearning to 'Make the Nation Great Again'.

The MAGA vision is vague enough to allow people from various walks of life to project different hopes of what it may entail. Most Trump voters were not necessarily fascist, but some were. Galvanized by the MAGA call was a heterogenous milieu of white nationalists, radical traditionalists, alt-right identitarians, conspiracy exposers, militias, neo-confederates, and sovereign citizens that Trump knowingly catered to. Millions of Americans shared the dream of national rebirth, though not necessarily what it was supposed to mean. By 2020 , some were disenchanted with what they had got. However, most remained enthused, and willing to dismiss every contradiction in Trump's words and deeds, and Trump increased his support by 11 million votes. Politics does not only depend on rational reason, but has an important affective dimension which fascism frequently caters to.

Trump's ousting will hardly be the end of story. Even if he sticks to golf and his Florida resort, Trump's 74 million voters and their grievances are still out there, and there are already contenders to his throne elected to congress and other institutions of mainstream politics.

\section{Ruth Wodak, Emerita Distinguished Professor of Discourse Studies at Lancaster University}

Many papers are currently discussing the so-called 'Trump-phenomenon': Is Trump himself a fascist? Is Trumpism a fascist movement? Is it still possible to use the concept of 'fascism' or does the term only refer to Mussolini's Fascism, Austro-Fascism, Mosley's Blackshirts or Spanish Franquismo of the 1920 and 193os? How do concepts such as 'alt-right', 'ultra-nationalism', 'extreme-right', 
'illiberalism', 'neo-authoritarianism', 'identitarianism' (and many more) relate to 'fascism' per se? Are these sanitizing, euphemistic concepts, attempting to avoid the negative connotations of the original term?

Actually, it does not make sense to lose oneself in terminological debates. Nor is it useful to speculate if Trump is or is not a fascist. Scholars have not had the chance to observe Trump's 'backstage' to be able to judge his personality features, apart from his publicly staged performances. Clearly however, when studying his biography, he frequently changed positions, for example, from supporting the Democrats to standing as Republican presidential candidate. In his thirst for power, money and public recognition, Trump could be viewed as an 'entertaining, very persuasive salesman', selling whatever it takes to achieve his aims, supported (and instrumentalized) by his ideologues.

Accordingly, following semioticians and discourse analysts such as Umberto Eco, Michael Billig and John E Richardson, a focus on the range of discursive and material practices realizing and implementing the ideological positions of the Trump administration, fostered by ideologues such as Steven Bannon, is recommended. Moreover, the socio-political, historical as well as situative contexts are relevant: Trump(ism) did not occur spontaneously; its ideological roots and rhetoric reach back to other nativist, extremist politicians like Barry Goldwater and fundamentalist, conservative movements like the Tea-Party which defied Barack Obama's presidency, supported and financed by (huge parts of) the GOP, media tycoons, and corporatism. Such movements which strategically manipulate the frustrations and anxieties of many people, while distracting them from their objective source, through offering emotionally and ideologically laden concepts such as obedience, honour, duty, the fatherland or race, and focusing on 'enemies' (i.e., scapegoats) who allegedly threaten the longed-for sense of community, can be defined as fascist. ${ }^{2}$

Trump's rhetoric applies salient discursive practices of fascism, both on-line and offline. On the one hand, he was the figurehead via his rallies and propagandistic Twitter politics (34,00o Tweets in the period of June 2015 until 8 January 2021); simultaneously, many diverse groupuscules on manifold digital platforms assembled under ( $\mathrm{t}$ )his umbrella, all connected with each other to construct a 'digital fascism. ${ }^{3}$ Scandalisation, provocation, transgression of taboos, hate incitement, and violation of norms and conventions were part and parcel of Trump's daily performance. Of course, such incidents not only guarantee many headlines and much (positive and negative) resonance; they

2 Martin Kitchen, Fascism (London: Macmillan 1976), 86.

3 Marik Fielitz and Holger Marks, 'Digital Fascism: Challenges for the Open Society in Times of Social Media,' CRWS Working Papers (2019), accessed February 12, 2021, https://escholarship. org/uc/item/87w5c5gp. 
also serve as distraction (i.e. 'dead cat-strategy') from specific policies intended to challenge and undermine democratic institutions, such as independent legislation, press freedom or democratic elections.

Typically, the rhetoric of Trump and his followers was based on the Manichean division of 'us' (the 'real, pure, white' Americans) and 'them' (Muslims, migrants, refugees, leftists and liberals, intellectuals, etc.); on mobilizing weaponized chants at rallies; and on encouraging his supporters to use violence against alleged enemies. As historian Timothy Snyder rightly maintained, 'this [Trumpism] has everything to do with race from top to bottom'.4 Trump explicitly contemplated that Hillary Clinton should be assassinated while continuously repeating the phrase 'crooked Hillary'; and he launched traditional antisemitic tropes of a 'Jewish World Conspiracy' claiming that philanthropist George Soros was responsible both for the influx of so-called 'illegal migrants' from Mexico and for political opposition. Moreover, serious media and facts were delegitimized, 'alternative facts' and lies legitimized. He openly sided with 'Proud Boys' and equated antisemitic, white supremacists with anti-fascist demonstrators. Such 'dangerous speech' ${ }^{5}$ was further enhanced by expressions of blatant machismo and misogyny. Obviously, discursive practices constitute and manifest realities - Trump's rhetoric thus accompanied and also enabled authoritarian policies and practices.

\section{Benjamin R. Teitelbaum, Assistant Professor of Ethnomusicology and International Affairs, University of Colorado Boulder}

Is fascism a historic or a diachronic phenomenon? If it is the latter, do today's far-right populists qualify as fascists?

I've always felt uninspired by these discussions because I consider their conditions too trivial. We can identify similarities and dissimilarities among far-rightists past and present, and we can argue that some generic visions and behaviours are more distinguishing of historic fascism, at least, than others. But I don't see how those analyses could allow us to take the crucial final step: to allege that a contemporary actor is not merely fascist-like but fully fascist. And yet as I equivocate in that historiographical debate, I unequivocally reject using the term to refer to figures like Donald Trump today, and do so based on epistemological and pedagogical grounds.

\footnotetext{
4 "This has everything to do with race from top to bottom" - Prof Timothy Snyder on Capitol siege,' Channel4.com, January 7, 2021, accessed February 12, 2021, https://www.channel4.com/news/ this-has-everything-to-do-with-race-from-top-to-bottom-prof-timothy-snyder-on-capitol-siege.

Dangerous Speech, accessed February 12, 2021, https://dangerousspeech.org/.
} 
Invoking the term today signals an end of inquiry. Whereas ideological mappings of the contemporary far-right might include jarringly unfamiliar monikers like anarcho-capitalists, race materialists, right-wing nihilists, and so on, everyone thinks they know fascism. Moreover, if there's one thing everyone knows about fascism, it's that they already know enough. It is the cause that liberal democracies cannot tolerate and the foremost manifestation of humanity's capacity for evil—what's left to say? It follows that professional and lay scholars often reflexively consider fascism as the utmost extreme in radical right-wing politics. If more contemporary far-right movements are regarded as facades concealing something more sinister, that something is fascism. Refer to a cause by another name, and you are participating in the act of deception.

I see little room in these conversations for the public to learn something new - about the past or the present. And it is not just lay audiences who suffer, for fascism talk gives us a dose of something we do not need. Far-right studies suffers from a troubling tendency to relish certainty over curiosity and regularity over inconsistency. It is lop-sided where many other fields strive toward balance, directing its attention heavily in favour of the macro over the micro, the general over the particular, and preferring to emphasize sameness rather than difference when comparing actors across sociocultural context and history. These are prerequisites to issuing condemnations of our subject that are not only impassioned, but simplistic. Multiple incentives drive this ur-paradigm, the most noble is the anxiety of understatement when dealing with political forces that can cause exceptional human suffering; as for physicians, the consequences of overdiagnosis may appear miniscule compared with the opposite. But we are also lured by vanity and the promise that media will amplify our words and names if we escalate the charges against contemporary right-wing radicals.

I would think differently about 'fascism' were its contemporary usage something other than a lynchpin of this paradigm; instead it is the banner of our certitudes and the content in our proclamations of our subject's regularity and dulness. I would think differently, also, were our field's challenges of another kind, were they actually (as some critics allege) to be found in excess relativism and apologetics. Until that becomes the case I will seek out labels that do not attempt to explain so much and that deprive us the comfort of familiarity.

\section{David Renton, independent scholar and author of Fascism: History and Theory (Pluto Press, 2020)}

My sense is that most specialists did not believe that Trump was a fascist prior to 6 January 2021. His occupation of the White House had not significantly 
increased the authoritarian resources of the US state, he did not build a one-party regime. What is more interesting to ask is therefore whether the coup of 6 January, had it been properly planned, would have taken him 'over the edge', to speak, converting a form of aggressive conservatism into something else?

One answer might be to recall that even the figures we know best, Hitler, Mussolini, Mosley, etc, were not born fascists but had to make themselves into the figures they became. We can imagine Trump poised between different political strategies, facing his own insurgent right-wing people, and telling himself: This is the crowd which might yet save my Presidency. In those circumstances, the decision to take power through a coup rather than an election, would have been the recognisable act of a military dictator and potentially that of a fascist. Undoubtedly, it would have changed Trump. He would have given a pledge to his supporters and would have a debt to them afterwards. He would be the same person, with the same previous history, but the logic of his decision to take power outside an election would have changed him.

The problem with the above thoughts, of course, is that they are counterfactuals. Plenty of others have been here before, imagining what almost happened but never did (Niall Ferguson's Virtual History ${ }^{6}$ is a good example of the flaws of this genre). The coup failed; every impression is that it was not meant to 'succeed'. It was a protest which found itself far closer to the symbols of power than its participants ever believed. The election was not close; the state never split.

There are two conclusions we could draw from this. Both address the susceptibility of our moment in history to capture by a violent, far-right. In one approach, the centre is surprisingly robust. It turns out that no plausible case could be made in favour of an American dictatorship. Even Trump-appointed judges and lawmakers would not consent to it.

In the other approach, we have just been given a warning, and not from history. Had the voting in the 2020 election been closer, so that a decent argument could have been made that the results were genuinely unclear, Trump would have faced a much more serious opportunity to keep himself in power. If so, we can assume that even more elected Republicans would have supported him, and even the armed forces might possibly have been split. At that point, the comparison with fascism would indeed have become meaningful.

We were supposed to be living in a post-fascist moment. It turns out that our society is more polarised, and more vulnerable to authoritarianism than we like to believe.

6 Niall Ferguson, ed., Virtual history: Alternatives and Counterfactuals (London: Picador, 1997). 


\section{Nigel Copsey, Professor of Modern History, Teesside University}

As the December 2020 special issue of Fascism bears out, the histories of fascism and anti-fascism are ineluctably interwoven. Nonetheless, there is still a regrettable tendency amongst scholars of fascism, working with their own strict, and rarefied definitions, to demean anti-fascist activism for oversimplification, distortion, and misrepresentation.

So how did self-proclaimed anti-fascists in the US respond to events at Capitol Hill on 6 January 2021? There were those who, not unexpectedly, rushed to label it a 'fascist coup'. The campaign group, Refuse Fascism, is one example. This group has, since its founding in the wake of Trump's 2016 election, consistently applied the term 'fascism' to the Trump/Pence administration. However, there are other self-proclaimed anti-fascists, many aligned to Antifa (which should be differentiated from Refuse Fascism), who are capable of offering a far more nuanced and sophisticated reading.

For It's Going Down (IGD), which is the leading digital platform for anarchist, anti-fascist, autonomous anti-capitalist and anti-colonial movements in the US, the crowd at Capitol Hill represented a coalition of 'Trumpian forces' and 'fascists' and were more precisely disaggregated into 'Proud Boys, neo-Nazis, groypers, MAGA supporters, QAnon followers, covID-truthers, and militia members.7 This was less an insurrection or revolt than a 'permitted fascist temper tantrum. ${ }^{8}$

As a historian drawn to researching anti-fascism (as well as fascism), I am very mindful that anti-fascists often subject their adversaries to misrepresentation. Yet anti-fascists can also be the subject of misrepresentation too, and in some cases, egregiously so. As we have seen, over the course of the last few years the Trump administration, and the Trump-supporting right-wing eco-system, have been instrumental in spreading disinformation about Antifa.

As late as 5 January 2021, Trump was still hankering for Antifa to be classified a 'terrorist organisation'. On that day - the day before the now infamous 'Save America' rally - Trump issued a presidential memorandum directing the Secretary of State to assess whether to classify Antifa a terrorist organisation

7 'This Week in Fascism \#91: Coalition of Fascist and Trumpian Forces Storm Capital,' itsgoingdown.org, January 11, 2021, accessed February 12, 2021, https://itsgoingdown.org/ this-week-in-fascism-91-coalition-of-fascist-and-trumpian-forces-storms-capitol/.

8 'Neither an Insurrection or Revolt: An Anarchist Response to the Permitted Fascist Temper Tantrum,' itsgoingdown.org, January 12, 2021, accessed February 12, 2021, https://itsgoingdown. org/neither-insurrection-nor-revolt-anarchist-response-dc/. 
under 8 USC §1182(a)(3)(B)(vi), and to consider listing Antifa in 9 FAM 302.5$4(B)(2)(U)$, thereby denying entry to the United States of 'aliens who have engaged or who are likely to engage in terrorist activity'. In one of his final presidential tweets, Trump warned:

Antifa is a Terrorist Organization, stay out of Washington. Law enforcement is watching you very closely!

—DONALD J. TRUMP (@REALDONALDTRUMP) JANUARY 5, 2021.9

Whether or not the timing of this memorandum was deliberate - a way to excuse potential violence by his supporters against counter-protestors on 6 January - is a moot point. Yet Antifa did not show. In their absence, rumours would later abound that Antifa had been amongst the Capitol rioters (a belief that forty per cent of respondents in one recent Anti-Defamation League poll thought true).

Needless to say, the 'false-flag' rumours were groundless (like many of the other spurious claims about Antifa that had preceded them). The reality, having recently interviewed anti-fascists activists in the US, is that anti-fascists do exercise significant levels of restraint, both offline and online. ${ }^{10}$ Exercising restraint appears more challenging for right-wing extremists, who, according to the ADL's Center on Extremism, were responsible for 9o per cent of all extremism-related murders in the United States in 2019. It is not for nothing that Antifa activists will tell you that fascism is an inherently violent ideology.

\section{Raul Cârstocea, Honorary Fellow in European History, University of Leicester}

Discussions of 'fascism' in our own time need to consider the fact that victory over fascism acted as the foundational myth of the post-war era on both sides of the Cold War, and certainly in the United States of America. Once established as a topos of ultimate evil and in that key decisively linked to Nazi

9 Donald J. Trump (@realDonaldTrump), 'Antifa is a Terrorist Organization, stay out of Washington. Law enforcement is watching you very closely!' Twitter, January 5, 2021, https:// twitter.com/realDonaldTrump/status/1346583537256976385?ref_src=twsrc ${ }^{\wedge}$ tfw.

10 Nigel Copsey and Samuel Merrill, 'Violence and Restraint within Antifa: A View from the United States,' Perspectives on Terrorism 14, no. 6 (2020): 122-138, https://www.jstor.org/ stable/2696473o. 
Germany rather than any other regime or movement, 'fascism' has become at once an extreme form of politics unlikely to be replicated in its exact historical manifestation, a label most of the contemporary far right except the very fringe will go to lengths to avoid, and a term of abuse for any unsavoury characters or organisations. Assessments of Trump as a 'fascist' have to navigate this unstable field, and the term of comparison for most academic and journalistic accounts has indeed been Nazi Germany (or, slightly more capaciously, Hitler and Mussolini).

Yet fascism as a political ideology covered a wide spectrum of individual actors and organisations, lacked an internationally unitary doctrine, and, due to its ultra-nationalism and insistence on its home-grown character, was always more context-specific than either socialism or liberalism. Its character also changed over time, was dependent on the position of the actors and their respective goals, which varied based on whether they were marginal organisations facing state opposition, large-scale movements with a serious bid to political power, or established regimes. Finally, while native fascisms differed greatly from Romania through Belgium to Britain, there were also 'para-fascists' and authoritarian regimes that adopted fascist ideological or stylistic trappings without embracing fascism's revolutionary impetus. It is against this background that I believe we need to conceptualise Trump's 'fascism' rather than against a simplistic 'Hitler' strawman, factoring in also the specifically American roots of his politics, whether they be racism or anti-communism. Results may vary, as they say, and we can conclude with confidence that, whether or not a 'fascist' himself, which is becoming less relevant, Trump did radicalise the Republican Party considerably and he did mobilise actual fascists to seek a violent overthrow of the establishment.

A final consideration is that fascism, like most other -isms, means different things to specialists and laymen. It is certainly overused to condemn those who challenge liberal democracy, just as it is used as a misnomer for authoritarianism, racism, antisemitism, or political violence. Here the role of the specialist is certainly one of providing more precision and clarity based on in-depth knowledge of historical fascism, some fundamental tenets discernible beneath the fluidity of its numerous iterations. But it may also be not to be entirely dismissive of the 'lay' meanings and to try to understand instead the mechanisms that account for its staying power. This might bring us back to that foundational myth and prompt us to question whether its reassuring narrative is not a blind spot to mutated viral strains that may constitute the 2.0 version of analogue fascism for our digital post-fascist present. 


\section{Maria Bucur, Professor, History and Gender Studies, Indiana University Bloomington}

The toxic charisma of Donald Trump swept through many spots of the world and took its toll on people in Eastern Europe along the way. In Romania, Trump was popular throughout his presidency with some small exceptions. He was simply America, and that meant not a communist and, in his case, definitely not a leftist. That made him more palatable from the perspective of a population that had come to hate communism with passion, and included a small but constant fringe of fascists posing for decades as anti-communist resisters. Ioan Antonescu's reputation is still pristine among a small group of enthusiasts, and Ioan Gavrilă Ogoranu, a fascist leader from the interwar period, still has a statue honouring him in downtown Deva.

The obsession with anti-communism has not receded in political and intellectual life over the past three decades. There are many among the younger generations of urban and foreign educated inhabitants who have moved on from this dominant trope. The superb documentary Collective ${ }^{11}$ is a great example of what happens when one moves beyond this obsession and judges governance on the basis of contemporary institutions and aspirations toward transparency and serving the common good without bias and 'lies told for power and for profit'.

But some prominent Romanians have remained enamoured with the notion that anti-communism is a crusade, just as the fascists stated in the 1940s. And some prominent academics, starting with the President of the Romanian Academy, Ioan Aurel Pop, have begun to combine this façade of anti-communism with discursive tropes close to the fascism of Ogoranu. A tribalist view of the Romanian family and society has gained increasing prominence in the public pronouncements of the President of the Academy, and accusations of cosmopolitism and globalism as forms of totalitarian control, equating them with communism and as Soros infiltrators, have started to slide towards essentialist fascist tropes.

A little over a decade ago, Sorin Lavric, then a rising star in the Romanian intellectual scene, won a major prize from the Romanian Academy for a study that was hailed as nuanced, balanced, and profound in its insights. ${ }^{12}$ It was a book dedicated to understanding the relationship between Constantin Noica, a prominent philosopher who participated in the fascist movement, and the

11 Alexander Nanau, Collective (2019).

12 Mirel Horodi, 'Un răspuns evaziv al Academiei,' Observator cultural, no. 510, January 28, 2010, accessed April 13, 2021, https://www.observatorcultural.ro/articol/un-raspuns-evazival-academiei/. 
Legion of the Archangel Michael. A number of scholars criticized the book for its 'balanced' view of the legionary movement, whose magnetism Lavric seems to go out of his way to explain in ways that suggest sympathies with the movement. And yet the book was also defended by many scholars in Romania and some overseas, where it was praised without reservation by other experts on 'moderation'.

Since December 2020, Lavric has become an open apologist for antisemitic, racist, misogynist, and anti-vaccine views espoused by the Alliance for Romanian Unification (AUR) party with which he has chosen to affiliate as a stepping stone towards a seat in the Senate. He now promises to start a war that will do away with the current political class. Lavric' party was proud to declare in December that they fully supported Trump, at a time when the President was challenging the democratic outcomes of the US election. More recently, one analysis described Lavric as a 'known apologist for Romanian fascism'.

The surfacing of fascist sympathies may have been facilitated by Trump, but they represent an older current that has gathered strength from the praises and general acceptance of such perspectives as part of the mainstream of scholarly production or cultural life. There is no reason to believe they will now subside. Trump is gone, but Lavric continues to publish in a prominent weekly literary journal and to participate in political life. In the US, the Charlottesville community has drawn a line in the sand and stated that, in dealing with Trump and the January 6th insurrection, accountability and justice have to precede unity. In Romania, accountability survives like a potted orchid, in small curated spaces, like documentary films.

\section{Brian Hughes, Associate Director at the Polarization and Extremism Research and Innovation Lab (PERIL) at American University}

Debates over the fascist merits of Trumpism have tended to concentrate on four conditions of dispute: 1) Trumpism's ambitions versus 2) its achievements 3) as a political-institutional regime and 4) as a cultural movement. The most heated debates seem to move effortlessly across these sectors, sometimes speaking past one another, sometimes resolving into antimonies of reason, in which either argument appears correct enough on its own merits yet remains incapable of either disproving or reconciling its opposition. I propose that these categories can be usefully realigned in Lacanian terms, 
which may help to resolve these antimonies. According to such a realignment, debate related to ideology and policy would belong to the register of the Symbolic. Here one might consider immigration under Trump, its continuities with Obama-era policy, and its function to create a class of Muslims and nonwhite Hispanics as homo sacer/the enemy within. Alternatively, debates best sorted into the register of the Real would be those concerning the inarticulable horror (or its absence) of actual events in the Trump presidency. Here one considers the forced rendition of protesters or the mass libidinal discharge of a Trump rally.

And here the Lacanian realignment exposes a critical gap in the preceding debates, that is, a tendency to neglect the register of the Imaginary. One may speculate as to why this is so. It seems that in debates which pit political scientists and historians against themselves and one another, media theorists have (for whatever reason) largely abstained. Yet media images offer a rich vein of evidence pointing to the fascistoid character of the Trumpist Imaginary. Consider the 'God Emperor' meme, which portrayed the president as a golden-haired cyborg messiah from the fantasy wargame Warhammer 4ok. This image appeared 9,6o2 times from 2015 - 2019 on 4chan alone. Or we might turn to the cartoons of Ben Garrison, where Trump is depicted as a smirking trickster with a bodybuilder's physique. More prosaically, we might consider the image of Trump as reality TV star and hero of his own autobiographies: an omnipotent captain of industry. Here we encounter not Trump the man but Trump the image - a fantasy ideal ego which his followers yearn to reflect. In the register of the Imaginary, where the Ur-capitalist god emperor resides, Trump not only meets the criteria of charismatic strongman proposed by Paxton and Payne, he exceeds them. In the capacity of a cosmic messiah, he not only meets the palingenetic criteria set forth by Griffin, he transcends them.

Of course, this does not resolve debates pertaining to the registers of the Symbolic and Real, but it does inform them. The Lacanian triad is inextricably linked and mutually influencing. Thus, questions of policy cannot be considered absent consideration of image, as the desires of the Symbolic proceed from the demands of the Imaginary. Nor can the horrors of the Trumpist Real be considered absent their Imaginary counterparts, as the needs (met or unfulfilled) that suffuse our experience of the Real provide the ground on which the fantasy figures of the Imaginary stand. By reorienting and expanding the question of Trumpism's fascist merits, we may yet do justice to this largely neglected-yet crucially important—dimension of the debate. 


\section{Roger Griffin, Emeritus Professor, Oxford Brookes University}

In many areas the gulf between academic and media knowledge - especially social media knowledge - resembles Africa's Great Rift Valley. Ever since Trump first exchanged the studios of reality TV for the world of surreality politics the word 'fascism' has hovered around his personal style of presidency like pesky midges. Constantly reached for by bloggers and journalists, their persistent use of it unwittingly blurs important differences between non-revolutionary and genuinely revolutionary forms of the far right when characterizing Trump's particular brand of populism. To make matters worse it has been sanctioned in the US by some high-profile academics such as Jason Stanley, Sarah Churchwell, Enzo Traverso and Federico Finchelstein.

Since the 1990s, a growing consensus has emerged within 'liberal academia' that fascism is a revolutionary form of ultranationalism that is not just driven by the desire to return the nation to an utterly mythical state of former greatness. Instead, it aspires to create a new, totalizing, postliberal, ethnically based national or international order purged of multiculturalism and pluralism. This was a project that Trump was far too simple-minded, racist, impulsive, narcissistic, materialistic, aporophobic (contemptuous of the poor), and Quixotic (not to say mentally unstable and delusional) in his thought processes to undertake. Unlike Mussolini and Hitler, he was far too concerned with self-aggrandizement to be a revolutionary strategist and leader and create the nucleus of a future leadership. Any sort of coherent ideology or political strategy of the sort needed for structural change was beyond him. In a way, to call Trump a fascist is an insult to fascism.

Obviously, other political constituencies saw him as fascist. Movements of the radical left such as Refuse Fascism did, hoping that the prospect of a Republican coup might galvanize the masses into a carrying out a Marxist revolution. Many in the alt-right saw him as one of theirs, an assumption encouraged by Trump's perverse response to the Charlottesville Unite the Right rally and his exhortation to the Proud Boys to 'stand by' in the debate with Biden (a request they complied in the Capitol incursion). Certainly, Trump displayed some of the 'antis' of fascism: misogyny, xenophobia, Islamophobia, the rhetoric of restoring a lost national greatness, populist appeals to chauvinism: but it was not consistently 'ultra-nationalistic', striving to create an organic (and hence ethnically exclusive) national community beyond the limits of democracy in a new order. Instead, his egomania led him to ride slipshod over core Enlightenment principles such as the separation of powers, due process, transparency, accountability of power, and respect for the letter and spirit of the constitution. 
So, what of Trumpism? A rabble made up of so many heterogenous elements from Catholic conservatives and apocalyptic Dispensationalists to survivalists, NRA fanatics, neo-Nazis and outlandish QAnon conspiracy theorists (most of whom disbanded once their saviour failed to defeat Biden and condemned the assault on the Capitol a 'heinous attack') can hardly be seen as a 'movement', let alone a cohesive ideological and political force. Trumpism may be a form of 'paranoid right' but not a fascist right. By encouraging the mob to storm the building Trump was being, not a fascist leader, but an 'ochlocrat'. Yet liberal humanists should take no comfort from Trump's lack of fascist credentials.

By spending four years crowbarring apart constitutional democracy from the liberalism and civil liberties that humanists, secular and religious, have struggled for over two centuries to weld together into 'liberal democracy', Trumpism and other forms of identitarian, ethnocentric populism have arguably posed a greater, more insidious threat to the credibility of democracy world-wide and the prospects for a sustainable world order than revolutionary extremism (which could have been efficiently put down by a display of state power). The digital pundits obsessed with Trump's putative fascism would be advised to devote more time to threats to liberal humanism emanating from within the parliamentary spectrum of politics, and perhaps spare a moment to check out the present state of fascist studies before irresponsibly raising spectres of interwar totalitarianism. 